\title{
Balkanologie
}

Balkanologie Revue d'études pluridisciplinaires

Vol. XI, n 1-2 | 2008

Volume XI Numéro 1-2

\section{Serbia's parties on the mend? That state of intra- party democracy in before and after regime change}

\section{Marlene Spoerri}

\section{(2) OpenEdition}

\section{Journals}

\section{Electronic version}

URL: http://journals.openedition.org/balkanologie/1453

DOI: 10.4000/balkanologie.1453

ISSN: 1965-0582

\section{Publisher}

Association française d'études sur les Balkans (Afebalk)

\section{Electronic reference}

Marlene Spoerri, « Serbia's parties on the mend? That state of intra-party democracy in before and after regime change », Balkanologie [Online], Vol. XI, n 1-2 | 2008, Online since 31 December 2008, connection on 17 December 2020. URL : http://journals.openedition.org/balkanologie/1453 ; DOI : https://doi.org/10.4000/balkanologie.1453

This text was automatically generated on 17 December 2020 .

(c) Tous droits réservés 


\title{
Serbia's parties on the mend? That state of intra-party democracy in before and after regime change
}

\author{
Marlene Spoerri
}

1 Almost a century after political parties' devolution into oligarchy was declared inevitable, rosy portrayals of political parties' democratic attributes remain few and far between. In old and new democracies alike, political parties are widely regarded as corrupt and opaque organizations, rarely practicing what they preach. ${ }^{1}$ Perhaps for this very reason, the past two decades have witnessed renewed interest in the inner workings of political parties. Unwilling to accept the deterministic theses offered by Ostrogorski, Michels and others, scholars have sought to explore the dimensions and prospects of intra-party democracy. According to some, intra-party democracy is not only desirable, it is possible. Proponents argue that not only are internally democratic parties more likely to select capable leaders, but that they are better positioned to achieve electoral success. In new democracies where public confidence in the political system tends to be low, intra-party democracy is thought to add much needed legitimacy to the democratic process, as well as to encourage an otherwise apathetic citizenry to take greater part in politics. Building on such claims, this paper examines the state of intra-party democracy in one new democracy, that of Serbia.

2 Since the onset of multiparty politics in 1990, political parties have been both a promoter of and a hindrance to what little political progress has been made in postcommunist Serbia. Many believe that a lack of intra-party democracy is at least partly to blame. Some have even gone so far as to assert that parties' democratic deficits have compromised the country's democratic trajectory. ${ }^{2}$ Certainly there is widespread agreement that during the period under Slobodan Milosevic's semi-authoritarian rule, parties on either side of the political spectrum were prone to oligarchy, if not outright autarchy. Not only were they highly centralized and prone to exclusivity, but in many cases party leaders' authoritarian tendencies ostracized the very individuals upon whom their support was meant to rest, a phenomenon which undoubtedly hurt rather 
than helped Serbia's democratic opposition. Yet the very same parties who suffered so blatantly from democratic deficits in the 1990s lay at the forefront of Serbia's democratic transition in October 2000, paving the way towards regime change and overseeing the process of democratization which followed. Has the onset of democracy in Serbia facilitated the democratization of the country's main political parties? By most accounts, the answer is no. Robert Michels' 'iron law of oligarchy' thus appears all too relevant in a Serbian context. This paper seeks to understand whether and to what extent this remains the case in a post-Milosevic context. Have Serbia's political parties evolved organizationally since the early 1990s? Are parties' organizational structures uniformly undemocratic or do differences exist with respect to different parties? To answer these questions this paper relies on domestic media coverage, interview with party members, as well as party statutes. Before delving into the specifics of Serbia's political parties, the case for (and against) intra-party democracy is laid forth.

\section{Intra-party Democracy}

3 Studies of intra-party democracy explore how political parties govern themselves. This includes how parties reach the decisions they make, what steps they take to ensure that those decisions are in tune with the will of their membership, and the lengths to which they go to protect the rights of members who do not share the majority opinion. More specifically, intra-party democracy, also known as internal party democracy, refers to those mechanisms that make parties' governance processes more inclusive and more representative of the party membership in its entirety. Studies of intra-party democracy focus on one or more of the following three dimensions of party organization: inclusiveness, referring to how extensive or representative the group of party decision-makers is; centralization, or how often decisions are made by only a single body ${ }^{3}$; and institutionalization, pertaining to how formalized the procedures of governance are. ${ }^{4}$ An internally democratic party is likely to boast governance methods which are inclusive, at least partially though not necessarily wholly decentralized, and institutionalized. By contrast, parties that suffer democratic deficiencies tend towards exclusivity (with a limited, unrepresentative set of party members holding decisionmaking powers), go to extremes in either centralization or decentralization (to such a degree that the final outcome does not reflect the will of the general party membership), and/or tend to be poorly institutionalized (although the opposite may also be true, as rules of exclusivity may be firmly in place).

Exploring how political parties govern themselves is invariably a complex, if not daunting task. Given the multiplicity of methods and mechanisms whereby parties seek to democratize such processes, providing an exhaustive illustration of the state of intraparty democracy is no doubt impossible. This analysis therefore limits itself to the three most significant sets of choices parties can make when crafting their organizational structures and practices. These include choices pertaining to: selection, or how parties decide on which policies to uphold, candidates to recruit, or leaders to support; accountability, meaning how parties ensure that the individuals and policies selected remain responsive to the will of the party membership; and tolerance, referring to how parties respond to competing perspectives or opinions from within party ranks. Though the vast majority of scholarly research focuses on selection procedures, mechanisms to ensure accountability and tolerance within political parties are 
arguably no less central to internal party democracy. After all, a party which boasts inclusive selection procedures but has not institutionalized the means by which to hold the selected accountable to the party membership cannot be said to be fully democratic, nor can a party which allows for inclusive internal suffrage but denies members the right to express their dissent in an organized fashion. The following pages examine the range of choices Serbia's political parties have made with respect to methods of selection, accountability, and tolerance. Each of these is assessed in light of the three dimensions of intra-party democracy (inclusivity, decentralization, and institutionalization) discussed above.

Bille writes that "it is common in politics for the written rules to be one thing, while the practice actually adopted when decisions are made and implemented is quite another." ${ }^{\prime 5}$ As such, this paper relies not only on party statutes but also first-hand interviews with party members and domestic media reports, both of which help to elucidate the state of intra-party democracy in practice. Still, it would be foolish to overstate the accuracy of even the most thorough of such analyses. Reliable empirical data is often hard to come by given the wealth of unofficial and more importantly untraceable channels at party leaders' disposal. In this respect, what Gallagher and Marsh call the 'secret garden' of politics extends far beyond candidate selection alone. ${ }^{6}$ Indeed, for all of scholars' attempts to shine light on the subject, internal party politics remains shrouded in mystery.

\section{Intra-party Democracy: Why it Matters}

6 In spite of the limitations confronting the study of intraparty democracy, scholars continue to devote serious attention to it. This is because advocates argue that intraparty democracy matters, not only for parties themselves but also for the larger democratic process. Arguments for intra-party democracy stem from these two separate modes of logic, one instrumental and the other normative in nature. As pertains to the latter, authors such as Bille argue that how parties govern themselves internally has a direct bearing on the larger democratic process. As he explains, "It is hard to understand how a regime can be classified as democratic if the political parties have an organizational structure that leaves no room for citizens to participate and have influence. The decision-making process within the parties, that is, the degree of internal party democracy becomes an interesting and even crucial issue for analysis." For parties to facilitate, rather than hinder, the democratic process, they must therefore practice what they preach. A similar argument is put forward by Augustine Titani Magolowondo, who writes that internal party democracy is one of a handful of institutional guarantees that parties must "fulfill if they [a]re to effectively meet what is expected of them in a democracy." ${ }^{8}$ Such normative lines of argumentation derive from the conviction that in drawing their members into the fold of the decision-making process, the distance between the elector and the elected is narrowed, and the legitimacy of the democratic process thereby enhanced.

7 A second line of defense of intra-party democracy pertains to its instrumental value. Unlike an oligarchic party, in which decisions regarding policy and candidates are made by a small elite or even a single individual, democratic parties incorporate their members into the decision-making process. Not only do they have a say in who represents them, but methods of accountability ensure that members also have a say in 
how they are governed. Should they disagree with their representatives or fellow members, they are free to voice such disagreements as they see fit. Members of democratic parties thus have a stake in both the policies that their parties' promote and the candidates who represent them. This, in turn, awards political parties a competitive edge. This includes party leaders and candidates who are thoroughly vetted and widely admired, policies and platforms that reflect the needs and interests of the party's membership, and a large, dependable pool of human and financial resources with which to launch electoral campaigns. Writes Susan Scarrow, “...parties using internally democratic procedures are likely to select more capable and appealing leaders, to have more responsive policies, and, as a result, to enjoy greater electoral success." Yet not everyone is equally convinced.

8 Critics of intra-party democracy tend to fall into one of three camps: those who think it is impossible to achieve, those who believe it is undesirable, and finally, those who warn that it is ultimately harmful. Members of this first camp include two of the subject's founders: Michels and Ostrogorski. Both were stark critics of parties' 'oligarchic' tendencies but found the pursuit of internal party democracy to be destined for failure. Hence Michels' unsettling conclusion "that this cruel game will continue without end." ${ }^{10}$ Whereas the first camp desires intra-party democracy but questions its feasibility, the second questions its very desirability. To this group of skeptics belong veritable party experts such as Schattschneider and Sartori, both of whom argue that intra-party democracy is irrelevant to the larger pursuit of democracy. For Schattschneider the implementation of intra-party democracy would be as selfdefeating as would an employer's wish to meet the demands of the employee at the expense of the consumer. Democracy, after all, exists between, not within, political parties. Members of the third camp go one step further. Critics such as Duverger and McKenzie argue that intra-party democracy threatens to make parties more vulnerable to internal strife, decreasing their efficiency and unity, and undermining their electoral competitiveness. In the words of Duverger, "Democratic principles demand that leadership at all levels be elective, that it be frequently renewed, collective in character, weak in authority. Organized in this fashion, a party is not well armed for the struggles of politics." ${ }^{11}$ The critique offered by May differs in its origins, but is no less damning. According to May's law of curvilinear disparity, parties that follow the will of their staunchest supports do so at their own peril. ${ }^{12}$ For May, party activists are partisan ideologues who seek to tilt the party to one polar extreme or another, the ultimate effect of which is the disenchantment of the average voter and a reduction of the party's overall competiveness. For this latter group of critics, intra-party democracy is not merely unfeasible or undesirable, it poses an outright danger to political parties.

\section{Intra-party Democracy: Why it is Necessary in Serbia}

9 Undoubtedly, the aforementioned arguments pose significant questions for advocates of intra-party democracy and deserve ample consideration. Yet for all their value, they are unpersuasive when applied to the subject of new democracies, where the issue is less about establishing intra-party democracy as such and more about the democratization of parties' governance processes. Indeed, if the major parties of Western Europe and North America are said to be oligarchies, than those of Eastern 
Europe and the former Soviet Union tend towards autocracy. Writing in 1995 Kopecky predicted that the organizational form most likely to emerge in post-communist Europe would be one in which members played only subsidiary roles and leaders were dominant. ${ }^{13}$ The work of van Biezen has confirmed these predictions. ${ }^{14}$ Throughout much of the post-communist world, parties are little more than personalized vehicles of self-aggrandizement, bearing scant identity apart from that which their leader bestows. In such an atmosphere, even basic measures to widen the circle of decisionmakers and expose party leaders to minimal oversight-while certainly falling short of the vision of internal democracy sketched above-would be a vast improvement. This is because new democracies, particularly those to emerge from the ashes of communism, suffer from the very same problems efforts to democratize party life help remedy.

To say that citizens of post-communist Europe have been disillusioned by postcommunist politics is to state the obvious. Distrust of political parties runs high, as does dissatisfaction with democracy. ${ }^{15}$ By almost any measure, whether one looks at the level of voter turnout, the strength of party membership, the degree of party identification, or the stability of voting patterns, support for party systems in the postcommunist world is lacking. Serbia is certainly no exception in this regards.

In a 2005 study conducted by the Center for Free Elections and Democracy (CESID), 63 percent of respondents declared themselves to have no trust in political parties. ${ }^{16} \mathrm{An}$ even higher number-65 percent-expressed no trust in executive authority. While a majority of those polled (57 percent) stated that they could identify with at least one party in Serbia, 43 percent could not. A 2006 opinion poll conducted by the International Republican Institute found similarly worrisome results. When asked about corruption in Serbia's parliament, almost 70 percent of respondents answered that the "majority of" or a "considerable number of" MPs were corrupt. ${ }^{17}$ Less than one in four respondents believed that corruption was confined to "only a small number of individual cases". Dissatisfaction with the status quo has led some in Serbia to question the very desirability of democracy. Although the CESID study found that 42 percent of respondents favored democracy to other forms of government, 20 percent stated that non-democracies were better in some cases, and 14 percent answered that nondemocracies and democracies were equal. There can be little doubt that lingering suspicions of their political representatives deserve at least part of the blame for such sentiments.

According to Zsolt Enyedi "Most scholars suspect that behind the generally low level of popularity of party politics stand the weak linkages between parties and social groups. ${ }^{18}$ Intra-party democracy has the potential to help parties address these issues. On the one hand, greater internal democracy means greater transparency and accountability, both of which serve to bolster parties' democratic credentials and add to their legitimacy. On the other hand, stronger links between party leaders and members may encourage an otherwise apathetic citizenry to partake in the democratic process. This in turn might facilitate the stabilization of partisan attachments, ultimately reducing electoral volatility and strengthening voter loyalty. ${ }^{19}$ Given the prospect that the democratization of parties' internal governance processes may positively contribute to Serbs' confidence in their party system, identifying existing democratic deficits is vital. The upcoming section does precisely this by laying out the state of internal party democracy in Serbia today. This is followed by a comparative analysis sketching the differences and similarities between political parties before and after regime change in 
an effort to understand how Serbia's parties have responded organizationally to the onset of their country's democratic transition.

\section{The State of Intra-party Democracy Today}

13 Serbia's first post-communist elections were held in December 1990. By that time, dozens of political parties had already sprung into action, most boasting no more than a handful of members. Over the course of the next two decades hundreds of political parties would be registered throughout Serbia, the vast majority of which would never make it into parliament. Of the parties that did, the following seven were arguably most important and will be the focus of this analysis: the Democratic Party (DS), the Democratic Party of Serbia (DSS), the G17 Plus, the Liberal Democracy Party (LDP), the Serbian Renewal Movement (SPO), the Serbian Radical Party (SRS), and the Socialist Party of Serbia (SPS). The differences between these parties were and remain extreme. While in the 1990s the SPS boasted unlimited access to state media, parties such as the DSS and SPO went virtually ignored. Whereas the SRS remains an ongoing proponent of a Greater Serbia, the LDP calls for full cooperation with the International Criminal Tribunal for the former Yugoslavia and has demanded that Serbia recognize the independence of Kosovo. Yet for all their differences, the parties which emerged in the aftermath of communism continue to share much in common, particularly when it comes to their internal make-up. This section provides an overview of the state of intra-party democracy today, beginning with a brief introduction to parties' basic organizational structures.

Like their counterparts in Western Europe, Serbia's parties are each composed of a number of party organs that oversee party life, the most important of which are the party assembly (also known as the congress), the main board, the presidency, and the executive board. ${ }^{20}$ In addition, specific party functionaries-the party president in particular-take on considerable (one might argue, excessive) authority and thus assume as organ-like status in their own right. Understanding how party authority is shared between each of these organs is the first step in uncovering the state of intraparty democracy in Serbia.

The party congress is the largest organ of the party, ranging from some six hundred members (DSS) to three thousand (SRS). Meeting once every two to four years, it is in the party congress that party platforms are approved, statutes are ratified, and party leaders are elected. In practice however, congress' functions are ceremonial. Its true authority lies in the rubberstamp with the ratification of key party documents and leadership positions following little, if any, deliberation. By contrast, the main board is smaller in size but boasts greater responsibilities. In almost all parties, this includes the task of establishing party politics and approving party strategy, including whether to enter republican-level coalitions with political adversaries. In some parties (the G17 Plus and SPS in particular), the main board enjoys truly significant prerogatives. For the SPS this includes the right to propose and confirm who in the party will serve as a member of parliament (MP). Yet such institutional arrangements are the exception rather than the rule. In most cases, the powers of the main board pale in comparison to those of the party president and presidency, who are often responsible for the formulation of party policy and strategy, as well as the proposal of party candidates and high functionaries. In general, it is the party president and his or her inner circle 
that is responsible for crafting party positions on pressing issues, with other party organs signing off on their decisions. Finally, the power of the executive organ tends to focus on oversight of local party work, including appointment of local party leaders as well as their dismissal. The following pages provide further clarification of the implications of such institutional arrangements for the state of intra-party democracy in Serbia today.

\section{Selection Procedures}

To understand the level of intra-party democracy in Serbia, it is necessary to examine the choices parties make with respect to: leadership selection, candidate selection, and policy selection. The following pages explore the lengths to which Serbia's political parties go to incorporate their members into each of these processes.

\section{Selecting Party Leaders}

Political parties in new democracies are often dominated by strong leaders and Serbia has proven to be no exception in this regard. ${ }^{21}$ In Serbia, party presidents play a central role in virtually all of the most meaningful decisions parties make. It is not uncommon, for example, for party presidents to be tasked with filling the most important positions within their parties, as well as dictating the work party organs conduct. ${ }^{22}$ In some instances, parties themselves have little identity save in terms of their presidents, hence the fact that most major parties in Serbia have never experienced a change in leadership. The means by which parties determine who their leaders are is thus one of the more important aspects of a party's organizational life.

Table 1 provides an overview of parties' leader selection processes as pertain to the election of party presidents. Perhaps the most telling conclusion that can be drawn from the table is just how few parties clearly delineate the process of leader selection. Indeed, one of the foremost problems afflicting the process is a lack of institutionalization. Under-institutionalization manifests itself in two respects: rules are either unspecified in party statutes or they are disobeyed in practice. As pertains to the former, part statutes are often unclear about who has the capacity to nominate a party leader and how such a nomination may be initiated.

Where party rules are explicitly stated, they are often violated in practice. A prime example of this is the rule of secret ballot. While all party statutes stipulate that party leaders are to be elected by secret ballot, the actual secrecy of such ballots is questionable. The SRS statute, for example, states that party presidents will normally be elected by secret ballot, and only in exceptional cases is election by public acclamation acceptable. ${ }^{23}$ In practice, it is the latter which is the norm and the former the exception as the SRS president is almost invariably elected by public acclamation in the SRS assembly. More worrisome is the DS, whose statute states that voting will be conducted exclusively by secret ballot. However, the DS's 2004 assembly meeting caused a stir when major violations of the electoral process were leaked to the press. ${ }^{24}$ It was alleged by the DS President of the Electoral Committee, among others, that prior to their submission the ballots of assembly delegates from local municipalities were screened by municipal presidents. Suspicions were further aroused in 2006 when in the days preceding the assembly meeting documents were uncovered which revealed the precise outcome of the assembly's decisions. 
Table 1: Leader Selection Procedures ${ }^{25}$

\begin{tabular}{|c|c|c|c|c|c|c|c|}
\hline & DS & DSS & G17 & LDP & SPO & SPS & SRS \\
\hline \multicolumn{8}{|c|}{ Procedures for electing party presidents are implemented at the: } \\
\hline National level only & & & - & - & - & - & $\mathrm{X}$ \\
\hline National and Sub-national levels & $\mathrm{x}$ & $\mathrm{x}$ & - & - & - & - & \\
\hline Sub-national level only & & & - & - & - & - & \\
\hline \multicolumn{8}{|l|}{ Candidates for president are nominated by: } \\
\hline Electoral Committee & & - & - & - & - & - & $\mathrm{X}$ \\
\hline Main board & & - & - & - & - & - & \\
\hline Municipal Boards & $\mathrm{X}$ & - & - & - & - & - & \\
\hline Assembly & & - & - & - & - & - & \\
\hline All party members & & - & - & - & - & - & \\
\hline \multicolumn{8}{|l|}{ Presidents are elected by: } \\
\hline \multicolumn{8}{|l|}{ Electoral Committee } \\
\hline \multicolumn{8}{|l|}{ Main board } \\
\hline Assembly & & $\mathrm{X}$ & $\mathrm{X}$ & $\mathrm{X}$ & $\mathrm{X}$ & $\mathrm{X}$ & $\mathrm{X}$ \\
\hline All party members & $\mathrm{X}$ & & & & & & \\
\hline \multicolumn{8}{|l|}{ Presidents are elected by virtue of: } \\
\hline Public acclamation & & & & & & & $\mathrm{X}$ \\
\hline Secret ballot & $\mathrm{X}$ & $\mathrm{X}$ & $\mathrm{X}$ & $\mathrm{X}$ & $\mathrm{X}$ & $\mathrm{X}$ & $\mathrm{X}$ \\
\hline \multicolumn{8}{|l|}{ Leader Selection rules are: } \\
\hline \multicolumn{8}{|l|}{ Entirely undefined in statute } \\
\hline Unclearly stipulated in statute & $\mathrm{X}$ & & $\mathrm{X}$ & $\mathrm{X}$ & $\mathrm{X}$ & $\mathrm{X}$ & \\
\hline Clearly stipulated in statute but deviated from in practice & & $\mathrm{X}$ & & & & & $\mathrm{X}$ \\
\hline Clearly stipulated in statute and upheld in practice & & & & & & & \\
\hline
\end{tabular}


The DS affair shone the spotlight on some very unsettling practices. In 2006, the party responded by unveiling a dramatic step towards greater intra-party democracy: the introduction of the primary system. Beginning in 2010, DS presidents will be elected by all party members through a secret ballot system. This represents a major departure from standard practice. At present, elections of party presidents remain highly centralized affairs occurring at a single meeting on a national scale. This meeting point is of course the assembly. ${ }^{26}$ Although staging an election of a party president in an assembly allows for greater inclusivity than it would the main board or presidency it is still a far cry from a truly inclusive election procedure, which would include the party membership in its entirety. For the proponents of intra-party democracy, one can only hope that the DS is setting a trend which its rivals will follow in years to come.

\section{Selecting Party Candidates}

21 Of no less vital concern for proponents of intra-party democracy is the matter of candidate selection. In any representative democracy, one of political parties' most important functions is that of recruiting individuals (i.e. candidates) who will run for office in their name. ${ }^{27}$ Table 2 provides an overview of MP selection methods. As can be seen, the process is inordinately centralized, exclusive and in contrast to leader selection processes, well institutionalized. There is little variation across the political spectrum in the process of MP selection, with the notable exception of the SPS. For most parties, the party president or presidency plays the central role by determining the potential pool of party MPs. It is thus this small party elite (in some cases, one individual) which draws up the list of MPs prior to an election. Although it is ultimately up to the main board to approve that list, they often do so with little deliberation. The SPS is the only true exception in this regards, in so far as its statute awards the party's main board the right to propose the draft of MPs, in addition to the right to confirm them.

Table 2: Candidate Selection

\begin{tabular}{|l|l|l|l|l|l|l|l|l|l|}
\hline \multicolumn{2}{|l|}{} & DS & DSS & G17 & LDP & SPO & SPS & SRS \\
\hline \multicolumn{2}{|l|}{ Process of MP selection conducted at: } & X & & X & X & X & X & X \\
\hline National level only & & X & & & & & \\
\hline Sub-national and National levels & & & & & & & \\
\hline Sub-national level only & & & & & & \\
\hline Electoral list of MPs proposed by: & X & & & $X$ & $X$ & & X \\
\hline President & & $X$ & $X$ & $X$ & & & \\
\hline Presidency & & & & & & X & \\
\hline Main board
\end{tabular}




\begin{tabular}{|c|c|c|c|c|c|c|c|}
\hline Municipal boards & $\mathrm{X}^{28}$ & $\mathrm{X}^{29}$ & & & & & \\
\hline \multicolumn{8}{|l|}{ Electoral list of MPs approved by: } \\
\hline \multicolumn{8}{|l|}{ President } \\
\hline Presidency & $\mathrm{X}$ & & & & & & \\
\hline Main board & $\mathrm{x}$ & $\mathrm{X}$ & $\mathrm{x}$ & $\mathrm{X}$ & $\mathrm{X}$ & $\mathrm{x}$ & $\mathrm{X}$ \\
\hline \multicolumn{8}{|l|}{ Assembly } \\
\hline \multicolumn{8}{|l|}{ Rules for candidate selection are: } \\
\hline \multicolumn{8}{|l|}{ Entirely undefined in party statute } \\
\hline Unclearly stipulated in party statute & & & & $\mathrm{X}$ & & & \\
\hline \multicolumn{8}{|l|}{$\begin{array}{l}\text { Clearly stipulated in party statute but deviated from in } \\
\text { practice }\end{array}$} \\
\hline Clearly stipulated in party statute and upheld in practice & $\mathrm{X}$ & $\mathrm{X}$ & $\mathrm{X}$ & & $\mathrm{X}$ & $\mathrm{X}$ & $\mathrm{X}$ \\
\hline
\end{tabular}

Serbia's parties are not bound by law to respect the MP list presented to voters on Election Day. Thus, once the votes are tallied and the number of mandates assigned, parties are free to pick and choose amongst their members as they see fit. In some cases (for example, the SPS), party statutes explicitly state that the final list of MPs may deviate from the electoral list. Few parties are explicit however in how mandates will ultimately be awarded. The DSS is an exception here, in so far as its statute states that the electoral list must be respected.

\section{Selecting Party Policy}

Another crucial aspect of intra-party democracy concerns the processes through which policy positions are crafted and selected. In more inclusive parties the rank and file is actively engaged at each step of the policy making process. Understanding who contributes to this process is central to uncovering the state of intra-party democracy in Serbia today. As Table 3 illustrates, the process of policy selection in Serbia is a topdown affair that suffers from a lack of institutional clarity. Although party statutes leave much to be desired with respect to clarity, it is evident that policy positions are crafted by the president and presidency and require the approval of the main board. Local municipal boards have little say in the process outside of their representatives' membership in these organs.

Table 3: Policy Selection

\begin{tabular}{|l|l|l|l|l|l|l||l|}
\hline & DS & DSS & G17 & LDP & SPO & SPS & SRS \\
\hline
\end{tabular}




\begin{tabular}{|c|c|c|c|c|c|c|c|}
\hline National organs only & $\mathrm{X}$ & $\mathrm{X}$ & $\mathrm{X}$ & $\mathrm{X}$ & $\mathrm{X}$ & $\mathrm{X}$ & $\mathrm{X}$ \\
\hline \multicolumn{8}{|l|}{ National and Sub-national organs } \\
\hline \multicolumn{8}{|l|}{ Sub-national organs only } \\
\hline \multicolumn{8}{|c|}{ Initial proposals for policy positions incorporate the viewpoints of: } \\
\hline President & $\mathrm{X}$ & & & $\mathrm{X}$ & $\mathrm{X}$ & & $\mathrm{X}$ \\
\hline Presidency & $\mathrm{X}$ & $\mathrm{X}$ & $\mathrm{X}$ & $\mathrm{x}$ & & $\mathrm{X}$ & \\
\hline Policy deliberation committee & $\mathrm{X}$ & $\mathrm{X}$ & $\mathrm{X}$ & $\mathrm{x}$ & $\mathrm{x}$ & $\mathrm{X}$ & \\
\hline Main board & & $\mathrm{X}$ & & & & & \\
\hline Assembly & & & $\mathrm{x}$ & & & & \\
\hline All party members & & & & & & & \\
\hline \multicolumn{8}{|l|}{ Policy positions approved by: } \\
\hline President & $\mathrm{X}$ & & & & & & $X$ \\
\hline \multicolumn{8}{|l|}{ Presidency } \\
\hline \multicolumn{8}{|l|}{ Policy deliberation committee } \\
\hline Main board & $\mathrm{X}$ & $\mathrm{X}$ & $\mathrm{X}$ & $\mathrm{X}$ & $\mathrm{X}$ & $\mathrm{X}$ & \\
\hline \multicolumn{8}{|l|}{ Assembly } \\
\hline \multicolumn{8}{|l|}{ All party members } \\
\hline \multicolumn{8}{|l|}{ Rules for determining policy positions are: } \\
\hline \multicolumn{8}{|l|}{ Entirely undefined } \\
\hline Unclearly stipulated & $\mathrm{X}$ & $\mathrm{X}$ & $\mathrm{X}$ & $\mathrm{X}$ & $\mathrm{x}$ & $\mathrm{X}$ & \\
\hline \multicolumn{8}{|l|}{$\begin{array}{l}\text { Clearly stipulated in party documents but deviated from in } \\
\text { practice }\end{array}$} \\
\hline $\begin{array}{l}\text { Clearly stipulated in party documents and upheld in } \\
\text { practice }\end{array}$ & & & & & & & $\mathrm{X}$ \\
\hline
\end{tabular}

24 The precise actors involved in the formulation of policy positions vary per party. Although the president or presidency are invariably most determinative, in most cases parties have established specific advisory councils who play a role in formulating party positions. The precise composition (i.e. inclusivity) of these councils varies per party. The parties boasting the most inclusive of such councils are the LDP, SPO and SPS, each 
of which incorporates both party members and non-party members. The LDP's statute even makes explicit mention of nongovernmental organizations. ${ }^{30}$ Other parties have taken a more exclusive approach by demanding that members of policy advisory councils also be members of the party. Unfortunately, the precise magnitude of these councils' decision-making powers is generally left unspecified in party statutes. Only in the DSS and DS are such councils awarded the status of party organ. In other parties, they are assigned only advisory powers and their decisions can thus be assumed to carry little weight. Nowhere do statutes stipulate that the proposals of the advisory board must be included in policy proposals, nor do they demand that these proposals be so much as considered by the main board. It is thus unclear to what effect they may be.

\section{Accountability}

All forms of representative democracy involve a trade-off between those who govern and those who are governed..$^{31}$ In the modern state citizens award impressive powers to political parties in exchange for guarantees of political accountability. According to the proponents of intra-party democracy, the authority of political party leaders should rest on a similar trade-off. Mechanisms must therefore exist through which party leaders can be held accountable to the party membership. This means, among other things, that: internal elections are free and fair; rules for the removal of party leaders are clearly codified; internal checks and balances exist and are fully functional and; key leadership positions are assigned fixed term limits. Serbia's political parties fail in each of these respects.

As was previously discussed, internal party elections in Serbia are neither free nor fair In most cases, the rules of electoral conduct are either unwritten or violated to such an extreme that their democratic character is jeopardized. This paper has argued that the under-institutionalization of the electoral process is in large part to blame. However, fraudulent elections are not the only respect in which Serbia's political parties fail to live up to the norms of democratic accountability. As Table 4 illustrates, the process of removing party leaders is no less problematic. As is the case with election procedures, rules governing the removal of party presidents are often left undefined in party statutes. Thus for the SPS and DSS, allrules pertaining to leader removal are conveniently absent, while for the G17 Plus and LDP they are only partially so. For both of these parties, while their assemblies are tasked with the power to remove party presidents, how such a procedure might be initiated is left unclear.

This is rectified in the cases of the DS, SPO, and SRS, where the rules for the removal of party presidents are clearly laid out in party statutes. However, almost two decades of multiparty politics suggests that such rules are rarely, if ever, upheld in practice. After all, not a single leader of any one of these parties has ever faced so much as a single vote of no confidence. Thus, despite the fact that he has been confined to a prison cell in the Netherlands for the past five years, the authority of Vojislav Seselj-President of the SRS-has yet to be called into question. Similarly, despite having been defeated in presidential elections on five separate occasions, the position of Vuk Draskovic as SPO party president remains firmly intact. Such facts suggest that even where procedural rules exist, they have few practical implications for the accountability process. 
Table 4: Accountability

\begin{tabular}{|c|c|c|c|c|c|c|c|}
\hline & DS & DSS & G17 & LDP & SPO & SPS & SRS \\
\hline \multicolumn{8}{|l|}{ The process of removing a party president occurs at: } \\
\hline National level only & $\mathrm{X}$ & $\mathrm{X}$ & - & $\mathrm{X}$ & & - & \\
\hline National and Sub-national levels & & & - & & $\mathrm{x}$ & - & $\mathrm{X}$ \\
\hline Sub-national level only & & & - & & & - & \\
\hline \multicolumn{8}{|l|}{ Procedures to remove a party president be may initiated by: } \\
\hline Presidency & & - & - & - & & - & \\
\hline Main board & $\mathrm{X}$ & - & - & - & $\mathrm{x}$ & - & $\mathrm{X}$ \\
\hline Municipal boards & & & - & - & $\mathrm{x}$ & - & $\mathrm{X}$ \\
\hline Assembly & $\mathrm{X}$ & & - & - & & - & \\
\hline Referendum (i.e. all party members) & & & - & - & & - & \\
\hline \multicolumn{8}{|l|}{ Final authority to remove a party president } \\
\hline \multicolumn{8}{|l|}{ Presidency } \\
\hline Main board & & & & & & - & \\
\hline Municipal boards & & & & & & - & \\
\hline Assembly & $\mathrm{X}$ & $\mathrm{X}$ & $\mathrm{X}$ & $\mathrm{x}$ & $\mathrm{x}$ & - & $\mathrm{x}$ \\
\hline Referendum (i.e. all party members) & & & & & & - & \\
\hline \multicolumn{8}{|l|}{ Rules for removing a party president are: } \\
\hline Entirely undefined in party documents & & & & & & $\mathrm{X}$ & \\
\hline Unclearly stipulated in party documents & & $\mathrm{X}$ & $\mathrm{X}$ & $\mathrm{X}$ & & & \\
\hline $\begin{array}{l}\text { Clearly stipulated in party documents but deviated from in } \\
\text { practice }\end{array}$ & $x$ & & & & $\mathrm{x}$ & & $\mathrm{x}$ \\
\hline $\begin{array}{l}\text { Clearly stipulated in party documents and upheld in } \\
\text { practice }\end{array}$ & & & & & & & \\
\hline
\end{tabular}

Perhaps the most worrisome of political parties' democratic deficits is the absence of functional checks and balances. Even when rules regulating the means for their removal exist, the powers of party presidents go virtually unrestrained. Much of the 
problem lies in the extensive freedoms party presidents are awarded with respect to the appointment or so-called 'recommendation' of top party functionaries. In the G17 Plus, for example, the president has the right to propose up to 60 permanent members of the main board.$^{32}$ In the DSS the prerogatives of the president stretch even further; he or she is charged with nominating all members of the presidency (including all the party's vice presidents), up to 24 members of the main board, three members of the party's monitoring board, as well as all members of the party's disciplinary commission. ${ }^{33}$ No less impressive are the powers of the SPO president who nominates members of the presidency ${ }^{34}$, the party's general secretary and director, the president of executive board, as well as the party's vice president. In the LDP, the party president has the right to nominate an unlimited number of members to be co-opted by the party's main board. ${ }^{35}$ In addition, he or she may recommend members of the presidency, the secretary of the party, as well as the secretary of the presidency. ${ }^{36} \mathrm{In}$ the case of the DS, the party president is charged with selecting candidates for deputy president, vice president, members of the presidency, president of the executive board, secretary and director of the party, secretary of the presidency, and members of the political council. ${ }^{37}$ The powers of the SRS president are no doubt most impressive. He or she can suggest candidates for the deputy president, main board, statutory commission, monitoring board, presidency, secretary general, vice presidents of main board, ten members of the executive board, and state functionaries..$^{38}$ Even for the SPS, which boasts the weakest party president, members of the presidency are elected at the suggestion of the party president..$^{39}$ Although presidential prerogatives are generally limited to the power of nomination rather than appointment, in practical terms it is the party president who is responsible for filling the most significant leadership functions within the party. As a consequence, they are often able to install loyal party members who are unlikely to question, let alone threaten, their authority. This phenomenon strengthens party leaders' positions horizontally and ultimately undermines any notion of checks and balances within the party.

The poor record of accountability in Serbia's political parties is further exacerbated by the lack of presidential term limits. No statute in Serbia stipulates a given number of years or terms after which a party president must step down. Thus, three of the eight parties under review have never experienced a change in leadership. This means, among other things, that Vojislav Kostunica, the president of DSS, has maintained his position for 16 years, while Vojislav Seselj has been SRS president for 17 years, and Vuk Draskovic the president of the SPO for 18 years. Having the possibility to be 'leader for life' does little to encourage leaders to accommodate other (popular) personalities in their party. Such individuals, no matter how qualified, are likely to be seen as potential competitors, and thus edged out of party life. A prime example of this occurred in 2004, when an up-and-coming member of DSS, Zoran Drakulic, rescinded his membership to the party. Over the course of just a few months time, Drakulic had gained a reputation as an active reformer seeking to change his party from within. Although his message had ample supporters-he outperformed the rest of his party in city-wide elections held that year-Drakulic's success stood to "endanger the internal equilibrium inside DSS and, unavoidably, called the existence of the steadfast party leader [Kostunica] into question." ${ }^{40}$ After learning that, despite Kostunica's personal assurance to the contrary, he would not be nominated as the party's vice president, Drakulic gave up his membership to the DSS and took an early exit from politics. When potential alternatives to party presidents are pushed out of party life in this fashion, the entire 
discussion of accountability becomes purely academic. After all, if party presidents can rest assured that rivals do not exist within their midst, they have little reason to fear for their removal.

\section{Tolerance}

One of the basic principles of intra-party democracy concerns the right of party members to voice their opinions openly and without fear of reprisal. Ideally, it also means that members have the right to organize on the basis of those opinions, even to form factions if they so desire. Table 5 examines the extent to which Serbia's parties tolerate internal dissent.

Table 5: Tolerance

\begin{tabular}{|c|c|c|c|c|c|c|c|}
\hline & DS & DSS & G17 & LDP & SPO & SPS & SRS \\
\hline \multicolumn{8}{|l|}{ Party members whose opinions differ from the majority: } \\
\hline $\begin{array}{l}\text { Have a right to express such opinions within the confines of } \\
\text { the party }\end{array}$ & $\mathrm{x}$ & - & $\mathrm{X}$ & $\mathrm{x}$ & - & $\mathrm{x}$ & - \\
\hline Face expulsion for expressing such opinions publicly & $\mathrm{X}$ & - & $\mathrm{X}$ & & - & $\mathrm{X}$ & $\mathrm{X}^{41}$ \\
\hline Have a right to express such opinions publicly & - & - & - & $\mathrm{x}$ & - & - & - \\
\hline Are permitted to organize on the basis of such opinions & - & - & - & - & - & $\mathrm{x}$ & - \\
\hline Have a right to form factions & - & - & - & - & - & & - \\
\hline \multicolumn{8}{|l|}{ Members of parliament are: } \\
\hline $\begin{array}{l}\text { Required to sign an agreement with the party stipulating } \\
\text { their rights and duties }\end{array}$ & - & - & $\mathrm{X}$ & - & - & - & - \\
\hline $\begin{array}{l}\text { Required to vote in accordance with decisions made by the } \\
\text { party organs }\end{array}$ & $\mathrm{x}$ & $\mathrm{X}$ & $\mathrm{X}$ & $\mathrm{x}$ & $\mathrm{x}$ & $\mathrm{x}$ & $\mathrm{X}$ \\
\hline $\begin{array}{l}\text { MPs are allowed to vote in parliament contrary to the } \\
\text { majority decision of the party }\end{array}$ & - & - & - & - & - & - & - \\
\hline \multicolumn{8}{|c|}{ Rules establishing the freedom of opinion of party members and MPs are: } \\
\hline Entirely undefined in party documents & & $\mathrm{X}$ & & & $\mathrm{X}$ & & $\mathrm{X}$ \\
\hline Unclearly stipulated in party documents & $\mathrm{X}$ & & $\mathrm{X}$ & $\mathrm{X}$ & & & \\
\hline $\begin{array}{l}\text { Clearly stipulated in party documents but deviated from in } \\
\text { practice }\end{array}$ & & & & & & & \\
\hline $\begin{array}{l}\text { Clearly stipulated in party documents and upheld in } \\
\text { practice }\end{array}$ & & & & & & $\mathrm{x}$ & \\
\hline
\end{tabular}


31 least partially) explicit with regards to members' freedom of opinion, and those who are entirely silent. To the former category belong the DS, G17 Plus, LDP, and SPS and to the latter, DSS, SPO, and SRS. In contrast to the former, the latter group's statutes concentrate solely on membership duties, in particular members' commitment to upholding party policies and programs. While the DSS statute makes no mention of members' rights to independent opinion, for example, it explicitly states that membership will be revoked as a consequence of the failure to abide by the party's decisions. ${ }^{42}$ One can only assume from this that tolerance for internal dissent in these parties is low.

By contrast the statutes of the DS, G17 Plus, LDP and SPS are more forthright with regards to the limits of their tolerance. While each of these parties permits its members to express their opinions in the confines of the party, only the LDP goes so far as to allow them to speak freely in public. ${ }^{43}$ Arguably, however, the most liberal political party when it comes to internal dissent is the SPS which, like all parties in Serbia, does not permit factions but does allow members to form groups on the basis of their divergent opinions, as doing so "contributes to internal party democracy". ${ }^{44}$ Although it is unclear on how a faction may be distinguished from a group, explicitly protecting members' rights to organize on the basis of minority opinions is quite unprecedented in Serbia.

Statutes aside, parties' failure to tolerate differences of opinion is well known. Although the SPS is the only party to state this explicitly, all parties in Serbia forbid the formation of factions. In many respects, however, their intolerance goes far beyond this. Although in theory most parties respect differences of opinion amongst their membership, in practice, individuals who are particularly vocal or steadfast in adhering to a minority opinion are unlikely to have a future in their party. This was most recently exhibited with the departure of Maja Gojkovic, the popular mayor of Novi Sad, from the SRS. But it is also visible in other parties, including the G17 plus and DS. A 2006 rift amongst members of the G17 Plus concerning the party's decision to support the government despite its failure to apprehend Ratko Mladic ended in the ouster of those party members who had supported the losing side (in this case, this included the party's then-president, Miroljub Labus). In December 2004 the DS revoked the membership of Cedomir Jovanovic and his supporters after they attempted to form a liberal democratic faction within the party. Parties' inability to accommodate competing perspectives within their midst is in fact a leading reason that so many members go on to form their own parties. The DS, for example, in addition to spawning the DSS and LDP, also accounted for formation of the Serbian Liberal Party and Democratic Center. The incessant formation of new party spin-offs compromises the stability of Serbia's party system and calls the democratic legitimacy of many parties into question.

The section has demonstrated that with respect to the areas of selection, accountability, and tolerance, Serbia's parties are largely centralized, exclusive and under-institutionalized. Parties are centralized in so far as their decision-making processes are often conducted in a single party organ on a national level. Local branches rarely have much, if any, say as to how their parties are run. Serbia's parties are exclusive to the extent that average party members have little access to the levers of the decision-making power and are rarely asked to contribute to the decisions their

Balkanologie, Vol. XI, $n^{\circ}$ 1-2 | 2008 
parties' makes. Finally, it had also been shown that Serbia's parties are underinstitutionalized in so far as the rules governing governance processes are either poorly elucidated or violated in practice.

Clearly, the state of intra-party democracy in Serbia leaves much to be desired. This verdict applies to all major parties in Serbia, irrespective of ideology or size. Thus the LDP, which holds just 13 seats in parliament and espouses libertarian ideals, shows little sign of being substantially more democratic than the SRS, which boasts 78 seats in parliament and advocates a nationalist ideology. By contrast the SPS-no less nationalistic than the SRS but significantly less successful (it has just 12 seats in parliament)-is not less democratic than the DS, the self-proclaimed leader of Serbia's bid for EU membership. While slight variations no doubt exist with respect to specific dimensions of internal governance-the SPS and LDP, for example, being slightly more tolerate of internal dissent, the G17 Plus and the SPS boasting somewhat weaker presidents, and the DS employing what will soon be the most inclusive leader election process-such differences are the exception not the rule. There is little evidence to suggest that any party in Serbia so much as resembles an internally democratic party.

That said, an analysis which concentrates solely on the current failings of intra-party democracy says little about the direction in which Serbia's parties are headed. Without understanding how parties' organizational practices have evolved since their founding, we can say little about the prospect for further reform. Nor can we gauge the degree to which the onset of democracy in Serbia has impacted upon parties' organizational development. The following section therefore offers a comparative perspective on the state of intra-party democracy before and after regime change.

\section{A Comparative Perspective}

37 By now it has become clear that political parties in Serbia suffer from enormous democratic deficits. Their governance processes are centralized, exclusive, and underinstitutionalized. Today's parties are, without exception, internally undemocratic. Yet this assessment is not without its share of caveats. To say that Serbia's parties are entirely oligarchic, even autarchic, would be an overstatement. Certainly there are faint indications that Serbia's parties do indeed see the need to democratize at least some aspects of their organizational life. Hence the DS's decision to introduce a primary voting system and the LDP's explicit consent for party members to speak their minds' publicly. But is there evidence to suggest that we are witnessing a gradual democratization of internal governance processes? Have parties become any more democratic or perhaps, less oligarchic, since the onset of democracy in Serbia?

Yes and no. In some respects Serbia's parties are certainly better institutionalized and less centralized today than they were at the outset of multiparty politics in 1990 . Yet there are also indications that Serbia's parties are actually less democratic than they were almost two decades ago. To verify these seemingly contradictory trends, this section begins by examining the state of intra-party democracy in the 1990 s.

of the seven political parties examined in this study, all but two (the LDP and G17 Plus) can trace their roots to the years either immediately preceding or following Serbia's first multiparty elections held in 1990. These parties' most formative years were thus spent in the highly politicized environment of Milosevic's Serbia. ${ }^{45}$ During this period, political parties were free to exist but did so amidst an onslaught of political, financial, 
and physical hurdles aimed at undermining their popular appeal. Serbia's democratic opposition responded to such pressures by launching large-scale political protests engaging thousands of citizens for weeks and sometimes months at a time. For parties to launch such protests effectively, they relied on a personalized form of politics based on their leaders' popular appeal and charisma. According to Vesna Pesic, a former party president herself and an avid critic of the wanton state of intra-party democracy today, the lack of intra-party democracy "...was understandable when the only goal was bringing down the Milosevic regime. It was not necessary to develop wider forms of internal democracy..." ${ }^{46}$ With their focus on hard-pressing issues such as coalition formation and regime change, party leaders struggled just to reach compromises amongst themselves, let alone their entire membership. The prospect of investing time and energy into the means and methods of intra-party democracy would likely have been unfathomable.

All the more surprising then that Serbia's first party statutes awarded such limited powers to top party brass. The DS statute of 1990 , for example, claimed its president's sole prerogative was that of calling the main board into session. ${ }^{47}$ The powers of the DSS president were portrayed as similarly meager in the party's first statute issued in 1992. Over the course of the following decade, however, party statutes awarded an ever greater array of powers to the position of party president. Thus by 1998 the DSS president formally had the right to coordinate party work, to propose candidates for the executive board and vice presidents, as well as to compose an electoral list of MPs. By 2001 he or she was also awarded the power to initiate a procedure of dismissal of the party presidency, council, and electoral board. Today, the president's powers are even more impressive. The increasing concentration of power in the hands of party leaders would indicate that Serbia's parties have becomes less, as opposed to more, democratic. Yet it also points to one of the major problems of studying intra-party democracy during this period; parties' first statutes were essentially fluid documents that mimicked trends in parties' development but did little to regulate them. Far more so than today, these documents were inexplicit with regards to even the most basic details of internal governance processes, such as the exact prerogatives of party organs or the manner in which elections were conducted. As such, a comparative analysis of intraparty democracy based on information obtained from party statutes is neither persuasive nor meaningful. A more helpful approach is to examine the evolution of parties as this occurred in practice. This comparison can occur across parties over time (i.e. the evolution of parties from $1990-2000$ ) as well as between them (i.e. parties formed before as compared to after regime change). The following pages begin with the former approach relying on each of the three aspects of intra-party democracy discussed above.

\section{Selection Procedures}

41 Selection procedures refer to the methods by which party leaders, candidates, and policy are chosen. This paper has demonstrated that such procedures are, with few exceptions, exclusive, centralized, and under-institutionalized. While improvements are notable with regards to the matter of institutionalization (these processes having been largely devoid of institutionalization in the 1990s), on the whole there has been little meaningful change over the course of the past two decades. 

such processes have changed for either the better or worse. Measuring levels of leadership turnover we see that of the five parties operational in the period between1990-2000 (DS, DSS, SPO, SPS, and SRS), just one experienced a change in leadership: the DS. By contrast, in the post-2000 period, three of our seven parties witnessed a change in leadership: the DS, G17 Plus and SPS. Yet of these, the death of a party leader prompted the transition in two of the three cases (Djindjic in the case of DS and Milosevic in the case of the SPS). Only the G17 Plus' transition from Miroljub Labus to Mladjan Dinkic in 2006 is a legitimate instance of leadership turnover. organizational change. In the 1990s it was common for parties to rely on what Vladimir Goati calls 'fictive' opponents. Such individuals stood no chance of defeating sitting party presidents but their candidacy awarded the electoral process an air of legitimacy. A prime example of this phenomenon occurred in 1990 at the SPS's first party assembly meeting. Slobodan Milosevic's 'opponent', Radmila Andjelkovic, conducted no campaign in the run-up to elections and made no substantive case for her appointment. As a consequence, few were surprised when she received a mere 66 votes to Milosevic's $1228 .{ }^{48}$ Yet since 2000, intra-party elections have become no more competitive. In some cases, parties continue to rely on fictive opponents, while in most they simply run as the sole candidate. The DSS's Vojislav Kostunica, for example, has run unopposed for some 16 years.

Perhaps the only party in Serbia whose electoral process is truly competitive is that of the SPS. Following the death of Milosevic in 2006, the SPS underwent a period of profound turmoil, during which the party split into two large blocs, one pro-reform and the other anti-reform. Until the staging of presidential election in December 2006 it remained unclear which of these groups would prove victorious..$^{49}$ The victory of Ivica Dacic-leader of the party's pro-reformist wing-marked the first time in Serbia's postcommunist history that a major political party boasted truly competitive elections. Yet apart from this one example there is little reason to believe that electoral processes have truly democratized. Although the DS's introduction of the primary system is certainly a major step in the right direction, it has yet to be implemented and its impact can therefore not yet be gauged.

As pertains to candidate and policy selection, a similar pattern is evident. While the rules governing such processes are no doubt better defined in contemporary statutes than they were a decade ago, they show little evidence of being either more inclusive or decentralized. The selection of MPs, for example, remains a thoroughly top-down affair in which average party members and local party branches simply have no say.

The evolution of policy selection has proven equally slow going. While the introduction of policy deliberation committees in the early 2000s adds some legitimacy to the process, it remains unclear how these committees actually contribute to the policymaking process. One might even argue that the process has become less inclusive, as NGOs continue to play an ever marginal role in the formulation of party policy. In the late 1990s, non-profits like the G17 (which later spun-off into the G17 Plus) and OTPOR played active roles in the policy-making process. After 2000 however, such relationships cooled, in some cases approaching outright hostility. Except in the case of the LDP, NGOs currently play no formalized role in either the crafting or selection of policy. The process has thus become less inclusive in this respect. 


\section{Accountability} the means and methods for ensuring that party leaders stay in check are few and far between. Although some parties have added clauses to their statues which roughly delineate how a party leader might be removed, no major party in Serbia-either in the 1990s or in the years that followed-has ever launched a procedure of no confidence, despite that the 2000s have only offered members more reason to seek the ouster of their leaders. Over the past five years, Vuk Draskovic has overseen his party's decline from prominence and Vojislav Seselj has been indicted for war crimes. Such phenomena would seem to offer ample pause for party members. Apparently however, they do not. This suggests that greater institutionalization aside, Serbia's parties are no more or less democratic with regards to standards of accountability than they were in the 1990s.

\section{Tolerance}

On the matter of tolerance equally somber conclusions may be drawn. No doubt, in many instances recent party statutes have drawn greater focus on the rights of party members, particularly as concerns free speech. Parties such as the LDP and SPS are noteworthy for the (comparatively) broad liberties they assign their members. Arguably the most truly democratic party in this regards in the SPS. As a result of an almost 50:50 split within the party, it has been forced to accommodate competing visions within its ranks. More than any other party, the SPS has proved adept at addressing competing interests and perspectives without forcing its (admittedly large) minority to branch off in new directions.

49

One might argue that growing tolerance is responsible for the decline in party fragmentation since 2000. During the 1990s, minority groups were incessantly branching off from mother-parties to launching rival organizations. The DS, for example was directly responsible for having spawned three separate parties during this period. Thus, in 1991 DS members formed the Serbian Liberal Party in protest of the DS's decision to partake in national elections. In 1992 Vojislav Kostunica and his followers formed the DSS after the party refused to join the Democratic Movement of Serbia (DEPOS). Later in 1996, the former president of DS, Dragoljub Micunovic, left the DS to form Democratic Center in protest of what he saw to be Zoran Djindjic's increasingly nationalistic tone. These parties, in turn, became a source of further offshoots. Thus, in 1997 after the DSS declared its unwillingness to join ranks with Zajedno, members broke paths with their party to form the Christian Democratic Party of Serbia. While the DS is certainly the most notorious of Serbia's parties with regards to the phenomenon of successor parties, it is certainly not alone. The Civic Alliance of Serbia, for example, was also the source of three different parties formed in the 1990s: the League of Social Democrats of Vojvodina, the National Peasant's Party, and the Social Democratic Union. In 1995, members were put off by Vuk Draskovic's authoritarian tendencies and left the SPO to form the Assembly National Party. Even the SPS, at the height of its powers in the early 1990s, could not accommodate competing views. In 1992, a group of members left the party to form the Social Democratic Party.

Balkanologie, Vol. XI, n 1-2 | 2008 
50 In the past few years, the number of parties formed as off-shoots has dropped considerably. The most recent examples are the creation of the LDP (an offshoot of DS), the formation of the Serbian Democratic Renewal Movement (formerly of SPO), and Maja Gojkovic's citizens group (an offshoot of the SRS). On the surface, this would seem to indicate that parties have become more accommodating of competing perspectives. More likely, however, it is simply reflective of the gradual institutionalization of the party system. Disgruntled party members have little reason to suspect that spin-off parties will be accompanied by greater electoral success. Instead of forming their own parties they are more likely to follow the path taken by the former president of G17 Plus, Miroljub Labus, and simply give up politics altogether.

51 One striking indication of just how intolerant political parties have become was witnessed with the passing of Serbia's first post-Milosevic constitution in 2006. Art. 102 of the constitution states that an MP is "free to irrevocably put his/her term of office at disposal to the political party upon which proposal he or she has been elected." ${ }^{50} \mathrm{In}$ contrast to the 1990s and early 2000s, Serbia's parties thus currently have the right to revoke their MP's mandates at a time and place of their own choosing. In practical terms this means that parties are fully justified in demanding that parliamentary candidates sign blank resignations prior to taking office. Parties may publicize such resignations when an MP fails to abide by the party's ruling. Thus, MPs are no longer able to divert from party line on even a single vote. This unprecedented ruling effectively represents the further institutionalization of the party's power over individual party members. It is a major step away from the further democratization of Serbia's political parties.

52 A second, and final approach, by which to compare the periods prior and after regime change is to contrast the parties formed in the 1990s (i.e. DS, DSS, SPO, SPS, SRS) to those formed post-2000 (LDP and G17 Plus). There is little doubt that the parties formed after 2000 are, programmatically speaking, Serbia's most progressive. Both the LDP and G17 Plus are staunch supporters of Serbia's EU aspirations. Both have been firm advocates of cooperation with the ICTY. The LDP, in particular, has awarded significant attention to the protection of minority rights in Serbia. Given their programs, one might expect similarly progressive organizational practices. Yet as tables $1-5$ illustrate, they do not perform substantially better than do any of the parties examined here, with the exception of the SRS. As has been shown, governance processes of the LDP are highly centralized. The party's president is awarded substantial prerogatives, making the LDP one of the most top-down parties examined here. Although it is significantly more tolerant of internal dissent than are other parties-it is after all the only party in Serbia which does not demand its MPs sign a blank resignation-this is the only area in which it excels. The G17 Plus offers an interesting point of contrast. A few years older than the LDP, the G17 Plus boasts more statutes through which to gauge the party's organization development. Over the years, these statutes indicate that internal governance processes have become less inclusive and less tolerant over time. The G17 Plus' current statute is in fact the only statute in Serbia to explicitly mention MPs' obligations to sign a contract proclaiming their obedience to the party (the infamous blank resignation). While the powers of the president are substantially more limited in the G17 Plus than they are in the LDP, they are not more limited than, say, the powers of the SPS president. This indicates that, on the whole, we should not 
expect parties established post-2000 to be harbingers of greater internal democratization.

\section{NOTES}

1. Transparency International, available at: http://www.transparency.org/global_priorities/ corruption_politics.

2. Orlović (Slaviša), Političke Partije i Moć, Beograd, Čigoja Stampa , 2002, pp.103-143.

3. The analytical distinction between inclusiveness and decentralization is often overlooked but is important nonetheless. There is after all no reason to assume a priori that a transfer of authority from a national to a local level will bring greater inclusivity. Deferring a decision from a national party congress which often includes thousands of party activists to local representatives who may number no more than 100 would, for example, make the governance process less rather than more inclusive.Reuven Y. Hazan and Gideon Rahat make this case persuasively in their chapter; "Candidate Selection: Methods and Consequences" in Katz (Richard), Crotty (William), éds., Handbook of Party Politics, London, Sage, 2006, pp.109-121. 
4. Scarrow (Susan), "Political Parties and Democracy in Theoretical and Practical Perspectives: Implementing Intra-Party Democracy”, National Democracy Institute for International Affairs (2005), 6.

5. Bille (Lars), "Democratizing a Democratic Procedure: Myth of Reality?: Candidate Selection in Western European Parties, 1960-1990”, Party Politics, 7 (2002) 3, pp.363-380, p.369.

6. Gallagher (Michael), Marsh (Michael), éds., Candidate Selection in Comparative Perspective: The Secret Garden of Politics (London: Sage, 1988).

7. Ibid, p.364.

8. Magolowondo (Augustine Titani), "Internal Party Democracy: The State of Affairs and the Road Ahead", Netherlands Institute of Multiparty Politics, 2007, 2.

9. Scarrow (Susan), "Political Parties and Democracy in Theoretical and Practical Perspectives: Implementing Intra-Party Democracy", National Democratic Institute for International Affairs (2005), 3.

10. Michels (Robert), Politics Parties: A Sociological Study of the Oligarchical Tendencies of Modern Democracy,New York, The Free Press, 1962, p.371.

11. Duverger (Maurice), Political Parties: Their Organization and Activity in the Modern States (London: Methuen, 1954), p.134.

12. May (John), "Opinion Structure of Political Parties: The Special Law of Curvilinear Disparity", Political Studies, 21( 1973), pp.134-151.

13. Kopecky (Petr), "Developing Party Organizations in East-Central Europe: What Type of Party is Likely to Emerge?", Party Politics, 1(1995) 4, 515-534.

14. Biezen (Ingrid van), Political Parties in New Democracies: Party Organization in Southern and EastCentral Europe, London, Palgrave, 2003.

15. Enyedi (Zsolt), "Party Politics in Post-Communist Transition", in Katz (Richard), Crotty (William), éds., Handbook of Party Politics, London, Sage, 2006, pp.228-238, p.233.

16. CESID, "Political Divisions in Serbia: Five Years Later", 2005, available at: http:// www.cesid.org/programi/istrazivanja/index.jsp.

17. International Republican Institute, "Serbia June 2006", (Massachusetts: Williams and Associates, 2006).

18. Enyedi (Zsolt),op. cit., p.233.

19. Bojinova (Denitza A.), "The Electoral Benefits of Internal Party Democracy? Theoretical and Practical Perspectives", working paper delivered at the Annual Meeting of the Midwest Political Science Associating, Chicago, April 20-23, 2006.

20. There are some exceptions to this. The SPS, for example, lacks a presidency. The LDP lacks an executive board. The DS, in addition to the president and presidency, has a mid-presidency which is charged with considerable prerogatives (see: DS Statute, 2006, Art. 48).

21. This is confirmed in the work of Ingrid van Biezen, Petr Kopecky, and Paul G. Lewis, among others.

22. The DSS is a prime example of this phenomenon. The president of the DSS nominates members of the party presidency. It is the presidency which formally has the most power within the party. However, it is the president himself who sets the agenda for the presidency and can even overturn its decisions if and when he so chooses (DSS Statute 2005, Art. 22)

23. SRS Statute (2006), Art. 63 and Art. 66.

24. Gligorijević (Jovana), "Skupština Demokratske Stranke: Kontrolisani Glasovi”, Vreme, 23 February 2006, No. 790, available at: http://www.vreme.com/cms/view.php?id=444128. This phenomenon was also confirmed during my interviews with former DS members.

25. For each of the following tables, $X$ indicates a 'yes' while - indicates that the party's most recent statute does not address the issue.

26. Given its final say in the election of a party president, the composition of the assembly says much about the inclusivity of the electoral process. Although specifics vary per party, all 
assemblies include representatives of local branches, some of which are appointed by virtue of their position within the local branch, while others are elected as assembly delegates by local party leaders. In addition, assemblies often include party MPs, members of party presidencies, members of the main board, representatives of youth and women's wings, etc.

27. See for example: Biezen (Ingrid van), "How Political Parties Shape Democracy", Center for the Study of Democracy, 4 (2004), p.16.

28. According the DS Statute, the president should take into account the suggestions of district municipal boards when drafting their proposals.

29. According the DSS Statute, the presidency should take into account the suggestions of district municipal boards when drafting their proposals.

30. LDP Party Statute 2007, Art. 41 and Art. 42.

31. Schedler (Andreas), "Conceptualizing Accountability", in Schedler (Andreas), Diamond (Larry), Plattner (Marc F.), éds., The Self-Restraining State: Power and Accountability in New Democracies, Boulder and London, Lynne Reinner Publishers, 1999.

32. G17 Plus Statute 2006, Art. 31.

33. DSS Statute 2007, Art. 22, Art. 16, Art. 86, Art. 15.

34. SPO Statute 2005, Art. 20.

35. LDP Statute 2007, Art. 24.

36. Ibid, Art. 29.

37. DS Statute 2006, Art. 39.

38. SRS Statute, Art. 58.

39. SPS Statute, 2006, Art. 37.

40. Goati (Vladimir), Partijske borbe u Srbiji u postoktobarskom razdoblju, Belgrade, Friedrich Ebert Stiftung, 2006, p.121.

41. The SRS statute states that members will face disciplinary actions for voicing contrarian opinions publicly. It does not go so far as to state that expulsion will be the result.

42. DSS Statute 2006, Art. 6.

43. LDP Statute 2007, Art. 17.

44. SPS Statute 2006, Art. 6.

45. Levitsky (Steven), Way (Lucan), "The Rise of Competitive Authoritarianism", Journal of Democracy, 13 (2002) 2, pp.51-65. For more on Serbia's regime type under Milosevic see: Gordy (Eric D.), The Culture of Power in Serbia: Nationalism and the Destruction of Alternatives, Pennsylvania, University of Pennsylvania, 1999. Thomas (Robert), The Politics of Serbia in the 1990s, New York, Columbia University Press, 1999.

46. Pešić (Vesna), "(De)Blokiranje tranzicije I unutarstranačka demokratija”, in Lutovac (Zoran), éd., Demokratija u Politickim Strankama Srbije, Belgrade: Friedrich Ebert Stiftung, 2006, p. 23.

47. DS Statute 1990, Art. 14.

48. Goati (Vladimir), op. cit., p.118.

49. See for example: "SPS Bira Predsednika", BBC Serbian, 2 December 2006, available at: http:// www.bbc.co.uk/serbian/news/2006/12/061202_sps.shtml.

50. Constitution of the Republic of Serbia (2006), Art. 102, available at: http:// www.parlament.sr.gov.yu/content/eng/akta/ustav/ustav_ceo.asp. 


\section{ABSTRACTS}

Has the onset of democracy in Serbia facilitated the democratization of the country's main political parties? By most accounts, the answer is no. Robert Michels' 'iron law of oligarchy' thus appears all too relevant in a Serbian context. This paper seeks to understand whether and to what extent this remains the case in a post-Milosevic context. Have Serbia's political parties evolved organizationally since the early 1990s? Are parties' organizational structures uniformly undemocratic or do differences exist with respect to different parties? To answer these questions this paper relies on domestic media coverage, interview with party members, as well as party statutes.

Est-ce que l'apparition de la démocratie en Serbie a facilité la démocratisation des principaux partis politiques du pays? Selon la plupart des constats, la réponse est non. La «loi d'airain de l'oligarchie» de Robert Michels apparaît donc tout aussi pertinente dans un contexte serbe. Cet article cherche à comprendre si et dans quelle mesure cela reste le cas dans un contexte postMilosevic. Est-ce que les partis politiques de Serbie ont évolué sur le plan organisationnel depuis le début des années 1990? Les structures organisationnelles des partis sont-elles antidémocratiques de manière uniforme ou bien existe-t-il des différences en fonction des partis? Pour répondre à ces questions, cet article s'appuie sur les médias locaux, des entretiens réalisés avec des membres de partis politiques, ainsi que les statuts de ces mêmes partis.

\section{INDEX}

Geographical index: Serbie

Mots-clés: Partis politiques, Démocratie 